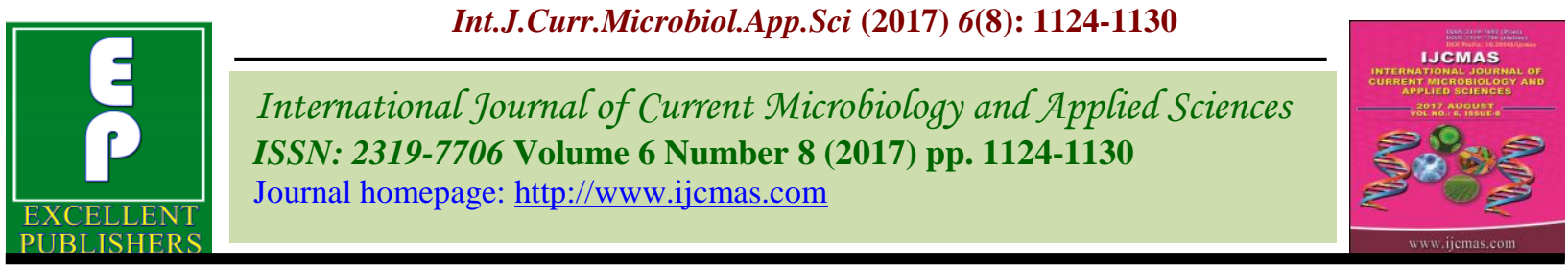

Original Research Article

https://doi.org/10.20546/ijcmas.2017.608.139

\title{
Impact of Different Packaging Materials on the Shelf Life of Sapota Fruits (Acharus zapota L.)
}

\section{Sudhir Pratap, Anjil Kumar*, Sujeeta, Vikas, Rupinder Singh, Bhupinder Singh and Harmanbeer Singh}

\author{
Department of Horticulture, School of Agriculture, Lovely Professional University, \\ Phagwara 144401, Punjab, India \\ *Corresponding author
}

\section{A B S T R A C T}

The present investigation was carried out with five different packaging material $T_{1}$ (LDPE), $\mathrm{T}_{2}$ (HDPE), $\mathrm{T}_{3}$ (Shrink), $\mathrm{T}_{4}$ and $\mathrm{T}_{5}$ (Cling) for increasing the shelf life of

Keywords

LDPE, HDPE,

Shrink, Cling,

Sapota fruit.

Article Info

Accepted:

14 June 2017

Available Online:

10 August 2017 sapota at different temperature and ambient temperature. The effect of packaging material on physiological loss in weight, decay loss, pulp: peel ratio, fruit length, fruit width, and fruit shape index, specific gravity was observed. The different treatments showed variation in physiological and physical parameters. Out of these five treatments, the treatment $\mathrm{T}_{3}$ (Shrink) showed best result as compared to other treatments. In the $T_{3}$ treatment, the shelf life of fruit increases to 18 days but in the other treatments the shelf life was only 15 days. The fruit without any treatments was edible only for 6 days. The minimum physiological loss in weight, decay loss and maximum pulp: peel ratio, fruit shape index was observed in $\mathrm{T}_{3}$ as compared to other treatments. By applying $\mathrm{T}_{3}$ (shrink), the shelf life of fruit is increased for several time period at optimized temperatures $\left(13-15^{\circ} \mathrm{C}\right)$.

\section{Introduction}

Sapota (Acharus zapota L.) is a long-lived, evergreen tree belongs to the family sapotaceae or 'naseberry family' in India it is also called as chiku and originated from Southern Mexico, Central America and the West Indies. India is considered as a largest producer of sapota in the world, yet it is considered as a minor crop in India. It is being cultivated on commercial scale in Maharashtra, Gujarat, Tamil Nadu, Andhra Pradesh, West Bengal, Uttar Pradesh, Punjab and Haryana. The area and production of sapota in India was estimated about 120740 hectare and 14.57 lakh tonne respectively.
Sapota is a climacteric fruit which ripens in about 5-7 days after harvest at room temperature. The storage period of ripe sapota fruits depends upon their respiration rate and storage environment. The storage life of sapota fruit is very short at ambient room temperature due to its highly perishable nature. Worldwide post-harvest losses in fruits are about $30-40$ per cent and it seems to be more in some developing countries (Panwar et al., 1980).Extension of shelf life may be possible by reducing the rate of transpiration and respiration, besides checking the microbial infection. For the enhance of 
shelf life of fruits uses of the polythene bags with proper ventilation Kariyanna and Reddy (1993) concluded that the increase in shelf life due to accumulation of $\mathrm{CO}_{2}$ with in the cover and its preservative effect. The thickness of polythene bags also influences shelf life of the fruits.

\section{Materials and Methods}

The present investigations were carried out at the horticulture laboratory of Lovely Professional University, Phagwara Punjab, from May to June, 2016.

\section{Selection and harvest of fruits}

The fresh sapota fruits of uniform size and well matured ones were selected. Apart, other traits of healthiness for fruits free from that of disease and bruising on skin were also taken into consideration for selection of fruits for harvest. The selected fruits were randomly picked from entire direction of the plant with the help of secateurs. The act of fruit harvest commenced during the month of June, collected and brought to Horticulture laboratory.

\section{Details of experiment}

The experiment was laid out in Completely Randomized Design (CRD). Eighteen fruits per treatment were taken and out of three replications, each replication contains 3 fruits. For decay loss, 18 fruits per treatment were stored separately and the treated fruits were kept for storage and observed at 2 days interval up to 18 days.

\section{Observations recorded}

\section{Physiological and physical parameters determination}

For the Physiological and physical parameters determination of fruits were randomly collected from the trees. And both physiological characteristics (Physiological loss in weight (\%), Decay loss (\%), Pulp: peel ratio) and physical characteristics (Fruit length $(\mathrm{cm})$, Fruit width $(\mathrm{cm})$, Fruit shape index and specific gravity) were determined by the methods described by AOAC.

\section{Statistical analysis}

The data were subjected to statistical analysis as outlined by Panse and Sukhatme (1985). The various comparisons were made after working out the standard errors and critical difference at 5 per cent level of significance.

\section{Results and Discussion}

\section{Physiological parameters}

Data depicted in tables 1, 2 and 3 showed that different packaging materials had significant effect on Physiological loss in weight (PLW $\%)$, decay loss $(\%)$ and pulp and peel ratio (\%) of sapota during storage.

Among treatments, maximum PLW was observed in $\mathrm{T}_{0}(22.97 \%)$ and minimum in $\mathrm{T}_{3}$ $(2.43 \%)$. PLW increase with duration of storage showing maximum PLW of weight on $9^{\text {th }}$ day of storage $(14.24 \%)$ and minimum on $3^{\text {rd }}$ day of storage $(3.22 \%)$.Interaction between treatment and storage was significant for PLW. The maximum value $(63.64 \%)$ was observed in $\mathrm{T}_{0}$ and minimum was observed in $\mathrm{T}_{2}(1.26 \%)$ on $9^{\text {th }}$ day of storage. In general, fruit loss of weight of sapota increases with increasing period of storage irrespective of packaging materials used. An increase in PLW of fruits in all the treatments with increasing period of storage was obvious due to the loss of moisture by evapo-transpiration and loss of reserved food material by respiration. During respiration process, various reserved food materials present in fruits are used. Secondly, the process of transpiration from fruit surface also continues 
even after harvest. Hence, due to the respiration and evapo-transpiration, the physiological loss in weight of fruits increased with increasing period of storage. The results are in conformity with the results of Kumar et al., (2000) in kinnow and Pandey et al., (2006) in apple. In the present study, the minimum PLW was observed in $\mathrm{T}_{3}$ and the maximum in $\mathrm{T}_{0}$ (control). This might be due to the restriction on diffusion of gases and feedback mechanism resulting into slow rate of evapo-transpiration and respiration. These results are in agreement with those observed by Joshua and Sathiamoorthy (1993) in sapota and Venkatesha and Reddy (1994) in guava. Among treatments, maximum decay loss was observed in $\mathrm{T}_{0}(21.68 \%)$ and minimum in $\mathrm{T}_{3}$ $(15.02 \%)$. Decay loss increases with duration of storage showing maximum decay loss on $15^{\text {th }}$ day of storage $(29.68 \%)$ and minimum on $3^{\text {rd }}$ day of storage $(3.49 \%)$. Interaction between treatment and storage was significant for decay loss.

The maximum value $(39.42 \%)$ was observed in $\mathrm{T}_{2}$ on $15^{\text {th }}$ day of storage and minimum was observed in $\mathrm{T}_{3}(1.81 \%)$ on $3^{\text {th }}$ day of storage. In general, decay loss of sapota increases with increasing period of storage irrespective of packaging materials used. Decay loss of fruits increased with the increase in storage period irrespective of treatments. This might be due to the more exposure of fruits to different micro-flora. With increasing storage period, the micro-flora got sufficient time to multiply. These results are in confirmation with the results of Jindal et al., (2005) in sapota. Higher decay loss of fruits in packaging materials of different thickness was due to the high humidity inside the polyethylene, which helped in multiplication of decay causing organisms. These results are in conformity with the results reported by Joshua and Sathiamoorthy (1993) in sapota. Among treatments, maximum fruit pulp and peel ratio was observed in $\mathrm{T}_{3}(5.66 \%)$ and minimum in $\mathrm{T}_{0}(1.38 \%)$. Interaction between treatment and storage was significant for fruit pulp and peel ratio. The maximum value $(5.99 \%)$ was observed in $\mathrm{T}_{3}$ on $15^{\text {th }}$ day of storage and minimum was observed in $\mathrm{T}_{0}(3.26 \%)$ on $3^{\text {th }}$ day of storage. In general, fruit pulp and peel ratio of sapota decreases with increasing period of storage irrespective of packaging material used. Pulp peel ratio depends upon the pulp and peel of individual fruits hence it vary among treatments as well as storage periods.

\section{Fruit physical parameters}

Data depicted in tables 4, 5, 6 and 7 showed that different packaging materials had significant effect on fruit length $(\mathrm{cm})$, fruit width $(\mathrm{cm})$, fruit shape index $(\mathrm{cm})$ and specific gravity of sapota during storage.

\section{Treatment details}

\begin{tabular}{|c|c|}
\hline Treatments & Treatment Details \\
\hline $\mathrm{T}_{0}$ & Control \\
\hline $\mathrm{T}_{1}$ & LDPE $(25 \mu)$ \\
\hline $\mathrm{T}_{2}$ & HDPE $(20 \mu)$ \\
\hline $\mathrm{T}_{3}$ & Shrink film $(10 \mu)$ \\
\hline $\mathrm{T}_{4}$ & Cling film $(15 \mu)$ \\
\hline $\mathrm{T}_{5}$ & Cling film $(23 \mu)$ \\
\hline
\end{tabular}


Table.1 Effect of different packaging materials on physiological loss in weight (\%)

\begin{tabular}{|c|c|c|c|c|c|c|}
\hline \multirow{2}{*}{ Treatments } & \multicolumn{5}{|c|}{ Storage Days } & \multirow{2}{*}{ Mean A } \\
\hline & 3 & 6 & 9 & 12 & 15 & \\
\hline $\mathrm{T}_{0}$ & 10.61 & 40.44 & 63.64 & 0.00 & 0.00 & 22.93 \\
\hline $\mathrm{T}_{1}$ & 2.18 & 3.11 & 6.16 & 6.79 & 7.20 & 5.09 \\
\hline $\mathrm{T}_{2}$ & 1.26 & 1.91 & 2.94 & 3.33 & 7.74 & 3.43 \\
\hline $\mathrm{T}_{3}$ & 1.46 & 1.77 & 2.30 & 2.94 & 3.73 & 2.43 \\
\hline $\mathrm{T}_{4}$ & 1.60 & 1.61 & 3.23 & 3.26 & 3.30 & 2.60 \\
\hline $\mathrm{T}_{5}$ & 2.28 & 4.15 & 7.19 & 7.22 & 7.67 & 5.70 \\
\hline Mean B & 3.22 & 8.83 & 14.24 & 3.92 & 4.93 & \\
\hline Factors & \multicolumn{2}{|c|}{ C.D. at 5\% } & \multicolumn{2}{|c|}{$\mathrm{SE}(\mathrm{d})$} & \multicolumn{2}{|c|}{ SE(m) } \\
\hline Factor(A) & \multicolumn{2}{|c|}{0.426} & \multicolumn{2}{|c|}{0.213} & \multicolumn{2}{|c|}{0.150} \\
\hline Factor(B) & \multicolumn{2}{|c|}{0.389} & \multicolumn{2}{|c|}{0.194} & \multicolumn{2}{|c|}{0.137} \\
\hline Factor(AXB) & \multicolumn{2}{|c|}{0.953} & \multicolumn{2}{|c|}{0.475} & \multicolumn{2}{|c|}{0.336} \\
\hline
\end{tabular}

Table.2 Effect of different packaging on Decay loss (\%)

\begin{tabular}{|c|c|c|c|c|c|c|}
\hline \multirow{2}{*}{ Treatments } & \multicolumn{5}{|c|}{ Storage Days } & \multirow{2}{*}{ Mean A } \\
\hline & 3 & 6 & 9 & 12 & 15 & \\
\hline $\mathrm{T}_{0}$ & 5.28 & 30.54 & 72.59 & 0.00 & 0.00 & 21.68 \\
\hline $\mathrm{T}_{1}$ & 3.99 & 12.57 & 20.26 & 25.87 & 38.11 & 20.16 \\
\hline $\mathrm{T}_{2}$ & 4.21 & 13.21 & 20.69 & 26.31 & 39.42 & 20.77 \\
\hline $\mathrm{T}_{3}$ & 1.81 & 7.58 & 13.80 & 21.68 & 30.28 & 15.02 \\
\hline $\mathrm{T}_{4}$ & 2.54 & 10.71 & 18.20 & 23.43 & 34.51 & 17.88 \\
\hline $\mathrm{T}_{5}$ & 3.08 & 10.94 & 19.00 & 24.00 & 35.71 & 18.54 \\
\hline Mean B & 3.49 & 14.26 & 27.42 & 20.21 & 29.68 & \\
\hline Factors & \multicolumn{2}{|c|}{ C.D. at 5\% } & \multicolumn{2}{|c|}{$\mathrm{SE}(\mathrm{d})$} & \multicolumn{2}{|c|}{ SE(m) } \\
\hline Factor(A) & \multicolumn{2}{|c|}{0.457} & \multicolumn{2}{|c|}{0.228} & \multicolumn{2}{|c|}{0.161} \\
\hline Factor(B) & \multicolumn{2}{|c|}{0.417} & \multicolumn{2}{|c|}{0.208} & \multicolumn{2}{|c|}{0.147} \\
\hline Factor(AXB) & \multicolumn{2}{|c|}{1.021} & \multicolumn{2}{|c|}{0.509} & \multicolumn{2}{|c|}{0.360} \\
\hline
\end{tabular}

Table.3 Effect of different packaging materials on Pulp: Peel ratio (\%)

\begin{tabular}{|c|c|c|c|c|c|c|}
\hline \multirow{2}{*}{ Treatments } & \multicolumn{5}{|c|}{ Storage Days } & \multirow{2}{*}{ Mean A } \\
\hline & 3 & 6 & 9 & 12 & 15 & \\
\hline $\mathrm{T}_{0}$ & 3.27 & 3.61 & 0.00 & 0.00 & 0.00 & 1.38 \\
\hline $\mathrm{T}_{1}$ & 3.90 & 3.69 & 5.18 & 4.33 & 3.69 & 4.16 \\
\hline $\mathrm{T}_{2}$ & 5.49 & 5.80 & 5.15 & 4.80 & 5.29 & 5.30 \\
\hline $\mathrm{T}_{3}$ & 5.80 & 4.77 & 5.82 & 5.92 & 5.99 & 5.66 \\
\hline $\mathrm{T}_{4}$ & 5.13 & 5.63 & 5.20 & 4.66 & 5.66 & 5.26 \\
\hline $\mathrm{T}_{5}$ & 3.94 & 5.50 & 4.77 & 5.40 & 5.43 & 5.00 \\
\hline Mean B & 4.59 & 4.82 & 4.36 & 4.18 & 4.33 & \\
\hline Factors & \multicolumn{2}{|c|}{ C.D. at 5\% } & \multicolumn{2}{|c|}{$\mathrm{SE}(\mathrm{d})$} & \multicolumn{2}{|c|}{$\mathrm{SE}(\mathrm{m})$} \\
\hline Factor(A) & \multicolumn{2}{|c|}{0.070} & \multicolumn{2}{|c|}{0.035} & \multicolumn{2}{|c|}{0.025} \\
\hline Factor(B) & \multicolumn{2}{|c|}{0.064} & \multicolumn{2}{|c|}{0.032} & \multicolumn{2}{|c|}{0.022} \\
\hline Factor(AXB) & \multicolumn{2}{|c|}{0.156} & \multicolumn{2}{|c|}{0.078} & \multicolumn{2}{|c|}{0.055} \\
\hline
\end{tabular}


Table.4 Effect of different packaging materials on fruit length $(\mathrm{cm})$ of sapota

\begin{tabular}{|c|c|c|c|c|c|c|}
\hline \multirow{2}{*}{ Treatments } & \multicolumn{5}{|c|}{ Storage Days } & \multirow{2}{*}{ Mean A } \\
\hline & 3 & 6 & 9 & 12 & 15 & \\
\hline $\mathrm{T}_{0}$ & 3.60 & 3.26 & 3.00 & 0.00 & 0.00 & 1.98 \\
\hline $\mathrm{T}_{1}$ & 3.90 & 3.79 & 3.61 & 3.53 & 3.41 & 3.64 \\
\hline $\mathrm{T}_{2}$ & 4.00 & 3.96 & 3.84 & 3.77 & 3.44 & 3.80 \\
\hline $\mathrm{T}_{3}$ & 3.99 & 3.93 & 3.80 & 3.61 & 3.50 & 3.77 \\
\hline $\mathrm{T}_{4}$ & 3.87 & 3.86 & 3.73 & 3.69 & 3.64 & 3.76 \\
\hline $\mathrm{T}_{5}$ & 3.82 & 3.69 & 3.51 & 3.47 & 3.39 & 3.58 \\
\hline Mean B & 3.87 & 3.74 & 3.59 & 3.00 & 2.90 & \\
\hline Factors & \multicolumn{2}{|c|}{ C.D. } & \multicolumn{2}{|c|}{$\mathrm{SE}(\mathrm{d})$} & \multicolumn{2}{|c|}{ SE(m) } \\
\hline Factor(A) & \multicolumn{2}{|c|}{0.103} & \multicolumn{2}{|c|}{0.051} & \multicolumn{2}{|c|}{0.036} \\
\hline Factor(B) & \multicolumn{2}{|c|}{0.094} & \multicolumn{2}{|c|}{0.047} & \multirow{2}{*}{\multicolumn{2}{|c|}{0.033}} \\
\hline Factor(AXB) & & & & & & \\
\hline
\end{tabular}

Table.5 Effect of different packaging materials on fruit width $(\mathrm{cm})$ of sapota

\begin{tabular}{|c|c|c|c|c|c|c|}
\hline \multirow{2}{*}{ Treatments } & \multicolumn{5}{|c|}{ Storage Days } & \multirow{2}{*}{ Mean A } \\
\hline & 3 & 6 & 9 & 12 & 15 & \\
\hline $\mathrm{T}_{0}$ & 3.42 & 3.14 & 2.89 & 0.00 & 0.00 & 1.89 \\
\hline $\mathrm{T}_{1}$ & 3.73 & 3.62 & 3.49 & 3.40 & 3.30 & 3.50 \\
\hline $\mathrm{T}_{2}$ & 3.79 & 3.77 & 3.70 & 3.61 & 3.38 & 3.64 \\
\hline$T_{3}$ & 3.69 & 3.60 & 3.48 & 3.42 & 3.34 & 3.50 \\
\hline $\mathrm{T}_{4}$ & 3.77 & 3.76 & 3.64 & 3.59 & 3.57 & 3.66 \\
\hline $\mathrm{T}_{5}$ & 3.70 & 3.65 & 3.46 & 3.30 & 3.24 & 3.47 \\
\hline Mean B & 3.68 & 3.59 & 3.44 & 2.89 & 2.80 & \\
\hline Factors & \multicolumn{2}{|c|}{ C.D. } & \multicolumn{2}{|c|}{ SE(d) } & \multicolumn{2}{|c|}{ SE(m) } \\
\hline Factor(A) & \multicolumn{2}{|c|}{0.106} & \multicolumn{2}{|c|}{0.053} & \multicolumn{2}{|c|}{0.037} \\
\hline Factor(B) & \multicolumn{2}{|c|}{0.097} & \multicolumn{2}{|c|}{0.048} & \multicolumn{2}{|c|}{0.034} \\
\hline Factor(AXB) & \multicolumn{2}{|c|}{0.237} & \multicolumn{2}{|c|}{0.118} & \multicolumn{2}{|c|}{0.084} \\
\hline
\end{tabular}

Table.6 Effect of different packaging materials on fruit shape index $(\mathrm{cm})$

\begin{tabular}{|c|c|c|c|c|c|c|}
\hline \multirow{2}{*}{ Treatments } & \multicolumn{5}{|c|}{ Storage Days } & \multirow{2}{*}{ Mean A } \\
\hline & 3 & 6 & 9 & 12 & 15 & \\
\hline $\mathrm{T}_{0}$ & 1.052 & 1.035 & 1.041 & 0.000 & 0.000 & 0.626 \\
\hline $\mathrm{T}_{1}$ & 1.045 & 1.044 & 1.036 & 1.038 & 1.033 & 1.039 \\
\hline $\mathrm{T}_{2}$ & 1.058 & 1.050 & 1.037 & 1.041 & 1.020 & 1.041 \\
\hline $\mathrm{T}_{3}$ & 1.081 & 1.086 & 1.092 & 1.055 & 1.060 & 1.075 \\
\hline $\mathrm{T}_{4}$ & 1.026 & 1.026 & 1.024 & 1.027 & 1.022 & 1.025 \\
\hline $\mathrm{T}_{5}$ & 1.032 & 1.008 & 1.011 & 1.048 & 1.043 & 1.028 \\
\hline Mean B & 1.049 & 1.042 & 1.040 & 0.868 & 0.863 & \\
\hline Factors & \multicolumn{2}{|c|}{ C.D. } & \multicolumn{2}{|c|}{ SE(d) } & \multicolumn{2}{|c|}{ SE $(m)$} \\
\hline Factor(A) & \multicolumn{2}{|c|}{0.006} & \multicolumn{2}{|c|}{0.003} & \\
\hline Factor(B) & \multicolumn{2}{|c|}{0.006} & \multicolumn{2}{|c|}{0.003} & \multicolumn{2}{|c|}{0.002} \\
\hline Factor(A X B) & \multicolumn{2}{|c|}{0.014} & \multicolumn{2}{|c|}{0.007} & \multicolumn{2}{|c|}{0.005} \\
\hline
\end{tabular}


Table.7 Effect of different packaging materials on specific gravity of sapota fruits

\begin{tabular}{|c|c|c|c|c|c|c|}
\hline \multirow{2}{*}{ Treatments } & \multicolumn{7}{|c|}{ Storage Days } & \multirow{2}{*}{ Mean A } \\
\cline { 2 - 7 } & $\mathbf{3}$ & $\mathbf{6}$ & $\mathbf{9}$ & $\mathbf{1 2}$ & $\mathbf{1 5}$ & \\
\hline $\mathrm{T}_{0}$ & 1.130 & 0.820 & 0.513 & 0.000 & 0.000 & 0.493 \\
\hline $\mathrm{T}_{1}$ & 1.120 & 1.100 & 1.080 & 1.070 & 1.050 & 1.084 \\
\hline $\mathrm{T}_{2}$ & 1.090 & 1.050 & 1.040 & 1.010 & 0.930 & 1.024 \\
\hline $\mathrm{T}_{3}$ & 1.120 & 1.110 & 1.073 & 1.040 & 1.030 & 1.075 \\
\hline $\mathrm{T}_{4}$ & 1.120 & 1.120 & 1.050 & 1.020 & 0.980 & 1.058 \\
\hline $\mathrm{T}_{5}$ & 1.260 & 1.170 & 1.150 & 1.050 & 0.920 & 1.110 \\
\hline Mean B & 1.140 & 1.062 & 0.984 & 0.865 & 0.818 & \\
\hline Factors & \multicolumn{2}{|c|}{ C.D. } & \multicolumn{2}{|c|}{ SE(d) } & \multicolumn{2}{c|}{ SE(m) } \\
\hline Factor(A) & \multicolumn{2}{|c|}{0.028} & \multicolumn{2}{|c|}{0.014} & 0.010 \\
\hline Factor(B) & \multicolumn{2}{|c|}{0.026} & \multicolumn{2}{c|}{0.013} & 0.009 \\
\hline Factor(AXB) & \multicolumn{2}{|c|}{0.063} & \multicolumn{3}{c|}{032} & \multicolumn{2}{c|}{0.022} \\
\hline
\end{tabular}

Among treatments, maximum fruit length was observed in $\mathrm{T}_{2}(3.80 \mathrm{~cm})$ and minimum in $\mathrm{T}_{0}$ $(1.98 \mathrm{~cm})$. Fruit length decreases with duration of storage showing maximum fruit length on $3^{\text {rd }}$ day of storage $(3.87 \mathrm{~cm})$ and minimum on $15^{\text {th }}$ day of storage $(2.90$ $\mathrm{cm})$.Interaction between treatment and storage was found to be significant for fruit length. The maximum value $(4.00 \mathrm{~cm})$ was observed in $\mathrm{T}_{2}$ on $3^{\text {rd }}$ day of storage and minimum was observed in $\mathrm{T}_{0}(3.00 \mathrm{~cm})$ on $9^{\text {th }}$ day of storage. In general, fruit length of sapota decreases with increasing period of storage irrespective of packaging material used. The results revealed that there was significant effect of packaging materials on fruit size. Fruit length was found decreasing during storage period under both ambient as well as cold storage conditions. At the day of harvest (zero day), all treatments showed maximum fruit size. It might be due to less moisture loss. More loss in moisture affects shrinkage and loss of turgidity of the fruits during storage. However, the lesser decrease of fruit length was observed in $T_{2}$ treated fruits which may be due to retarded process of respiration and transpiration or less rate of the moisture loss from the fruits. Among treatments, maximum fruit width was observed in $\mathrm{T}_{4}$ $(3.66 \mathrm{~cm})$ and minimum in $\mathrm{T}_{0}(1.89 \mathrm{~cm})$. Fruit width decreases with duration of storage showing maximum fruit width on $3^{\text {rd }}$ day of storage $(3.68 \mathrm{~cm})$ and minimum on $15^{\text {th }}$ day of storage $(2.80 \mathrm{~cm})$ Interaction between treatment and storage was found to be significant for fruit width. The maximum value (3.79) was observed in $T_{2}$ on $3^{\text {rd }}$ day of storage and minimum was observed in $\mathrm{T}_{0}$ $(2.89 \mathrm{~cm})$ on $9^{\text {th }}$ day of storage. In general, fruit width of sapota decreases with increasing period of storage irrespective of packaging material used. The results revealed that there was significant effect of packaging materials on fruit size. Fruit width was found decreasing during storage period under cold storage conditions. At the day of harvest (zero day), all treatments showed maximum fruit size. It might be due to less moisture loss. More loss in moisture affects shrinkage and loss of turgidity of the fruits during storage. However, the lesser decrease of fruit width was observed in $T_{4}$ treated fruits which may be due to retarded process of respiration and transpiration or less rate of the moisture loss from the fruits. Among treatments, maximum fruit shape index was observed in $\mathrm{T}_{3}$ (1.075 $\mathrm{cm})$ and minimum in $\mathrm{T}_{0}(0.626 \mathrm{~cm})$. Fruit shape index decreases with duration of storage showing maximum fruit shape index on $3^{\text {rd }}$ day of storage $(1.049 \mathrm{~cm})$ and 
minimum on $15^{\text {th }}$ day of storage $(0.863$ $\mathrm{cm})$.Interaction between treatment and storage was found to be significant for fruit shape index. The maximum value $(1.092 \mathrm{~cm})$ was observed in $\mathrm{T}_{3}$ on $9^{\text {th }}$ day of storage and minimum was observed in $\mathrm{T}_{5}(1.008 \mathrm{~cm})$ on $6^{\text {th }}$ day of storage. Fruit shape index may vary among different treatments as it depends upon the length and width of individual fruit. Among treatments, the maximum value $(1.110 \%)$ was observed in $\mathrm{T}_{5}$ and minimum value $\mathrm{T}_{0}(0.493)$. In general, specific gravity of sapota decreases with increasing period of storage. Maximum specific gravity $(1.140 \%)$ was observed on $3^{\text {rd }}$ day of storage and minimum specific gravity $(0.818 \%)$ was observed on $15^{\text {th }}$ days of storage by using standard formula. Interaction between treatment and storage was found to be significant for specific gravity. The maximum value $(1.260 \%)$ was observed in $\mathrm{T}_{5}$ on $3^{\text {rd }}$ day of storage and minimum was observed in $\mathrm{T}_{0}$ $(0.513 \%)$ on $9^{\text {th }}$ day of storage. In general, specific gravity of sapota decreases with increasing period of storage due to decreasing in weight of fruit irrespective of packaging material used.

\section{Acknowledgement}

We are highly grateful to Department of Horticulture for providing all facilities related to our research work.

\section{References}

Jindal, S., Beniwal, L. S., Godara, N. R. and Sihag, R. P. 2005. Studies in shelf life of sapota fruits with polyethylene packging. Haryana journal of horticultural science, 34(3-4):253-255.

Joshua, P. and Sathiamoorthy, S. 1993. Storage of sapota fruits in polyethylene bags. South Indian Horticulture, 41(6):368-369.

Kariyanna, K. M., Bojappa and Reddy, T. V. 1993. Influence of some Harvest Treatments on ripening and quality of sapota fruits. Golden Jubilee Symposium, Horticultural Research on Changing Scenario, Abstract, p: 300. (Banglore, May 24-28, 1993).

Kumar, J., Sharma, R. K. and Singh, R. 2000. The effect of different methods of packing on the shelf life of kinnow. Haryana Journal of Horticultural Sciences, 29(3/4):202-203.

Pandey, G., Verma, M. K. and Tripathi, A. N. 2006. Studies on storage behavior of apple cultivars. Indian Journal of Horticulture, 63(4):368-371.

Panwar, J. S. 1980. Post-harvest physiology and storage behavior of berfruits (Ziziphus Mauritian Lamk.) in relation to temperature and various treatments cv. Umran and Kaithali. Ph.D. Thesis, Haryana Agricultural University, Hisar, Haryana, India

Panse, V.G. and Sukhatme, P.V. 1985. Statistical Methods for Agricultural Workers. Indian Council of Agricultural Research Publication, 87-89.

Venkatesha, M. and Reddy, T. V. 1994. Use of polyethylene bags to extend the shelf life of guava (Psidium guajava L.) fruits. Indian Food Packer, 48(5):5-10.

\section{How to cite this article:}

Sudhir Pratap, Anjil Kumar, Sujeeta, Vikas, Rupinder Singh, Bhupinder Singh and Harmanbeer Singh. 2017. Impact of Different Packaging Materials on the Shelf Life of Sapota Fruits (Acharus zapota L.). Int.J.Curr.Microbiol.App.Sci. 6(8): 1124-1130.

doi: https://doi.org/10.20546/ijcmas.2017.608.139 